\title{
Access and Inequality in US Higher Education: Policy Issues
}

\author{
David Dill
}

\section{INTRODUCTION}

The US transition to mass post-secondary education after World War II and its positive socioeconomic impact on American society are often regarded as a primary motivation for the "massification" of other national systems of higher education over the last 25 years. However, while there are a number of estimable policies and practices in US higher education, including its nationally competitive funding of academic research, its management, and governance of research universities, and its structure and collegial organization of research doctoral programmes, the effectiveness of current American policies governing access to higher education is more debatable. For example, the percentage of recent US high school graduates enrolled in college rose from 45\% in 1960 to 67\% in 1997 (NCES, 2018), but has stagnated since then. The US now trails a number of OECD nations in the percentage of young adults who have completed tertiary education (OECD, 2019). In addition, American public

\section{Dill $(\bowtie)$}

University of North Carolina, Chapel Hill, NC, USA

e-mail: ddill@email.unc.edu

(C) The Author(s) 2022

O. Tavares et al. (eds.), Equity Policies in Global Higher Education, Issues in Higher Education, https://doi.org/10.1007/978-3-030-69691-7_3 
schooling at the secondary level was traditionally perceived as more "democratic" than systems in Europe and contributed to the belief that social mobility was greater in the US than in other developed nations (LeTendre et al., 2003). But these beliefs now clash with contemporary economic and demographic evidence indicating many EU nations, particularly the Scandinavian countries, have both higher earnings mobility across generations and lower levels of economic inequality than does the US (OECD, 2015,2018 ).

The reasons for these observed differences in economic inequality and access to higher education in the EU and US are complex. The Nobel Laureate in Economics, James Heckman (2019), summarizes the expected economic rates of return to society of various public investments in human capital, which include higher education. As Heckman notes, in most OECD nations achieving a tertiary degree increasingly improves one's lifetime earnings. But public investment in effective prenatal healthcare, preschool education, and schooling actually provide a greater rate of return to society than public investments in higher education because of their substantial impact on the social and economic success of lower income individuals. The design of these public policies also influences access to higher education. The US varies from most EU nations in not providing universal prenatal healthcare, universal pre-school day-care and educational programmes. In addition, the US federal governance system places major responsibility on the 50 states for the organization and financing of primary and secondary education and within most states school financing is largely by local property taxes. Consequently, low-income areas in the US have poorer quality schools. Also, in comparison to many EU nations, the US has no national curriculum or exams for primary and secondary education, although standardized tests developed by the independent College Board (SAT Exam) and American College Testing (ACT Exam) are available to help inform college entrance decisions in the 50 states. Finally, US college and university admissions decisions are primarily the responsibility of each public and private institution.

Some of the differences in college entrance policies between the US and other countries were publicized by recent court cases regarding access to American institutions of higher education. One set of cases revealed wealthy parents bribing corrupt testing and college officials to guarantee entry of their children into elite, selective research universities (Chappell \& Kennedy, 2019). These recent cases also confirmed substantive research on access to selective US colleges and universities (Arcidiacono et al., 
2019; Bowen \& Levin, 2003; Shulman \& Bowen, 2000), which has discovered biased admissions procedures favouring athletes recruited to play on college sports teams, children of college alumni (so-called legacies), as well as the children of institutional faculty members. These observed biases in selective college and university entrance standards raise legitimate questions as to the equity and fairness of access to current US higher education.

In public policy equity or fairness is often defined utilizing the economic concepts of horizontal and vertical equity (Weimer \& Vining, 2017). With regard access to higher education, as outlined in Amaral's introductory chapter, horizontal equity can be conceived as the equal treatment of valid applicants. Contrastingly, vertical equity can be conceived as special treatment given to those valid higher education applicants with the greatest financial need. Both these forms of equity are visible in higher education access policies in the US and EU. Under the assumption one can learn from public policy failures as well as successes, this chapter reviews the research on the equity of access to US bachelor degreegranting institutions of higher education ${ }^{1}$ with an emphasis on the impacts of financial aid policy, informational and behavioural constraints for lower income applicants, and affirmative action programmes.

\section{US Financial Aid Policy}

The economist Nicholas Barr (2009) has provided an economic framework for evaluating the efficiency and equity of national policies supporting higher education, and these guidelines can be usefully applied to explicate US financial aid policy. First, Barr argues because of its influence on national economic performance and on individual life chances, developed as well as emerging economies now require mass, high quality higher

\footnotetext{
${ }^{1}$ Higher education in the US also includes "community colleges," primarily two-year public institutions granting vocational certificates as well as associate degrees for transfer to a bachelor's degree-granting college or university. In contrast to most bachelor's degreegranting institutions, community colleges provide access to anyone who is a high school graduate. Consequently, the majority of community college entrants come from the bottom half of the economic distribution and include many working class and minority students. But $62 \%$ of students entering community colleges fail to complete a certificate or degree, and while $81 \%$ of those entering aspire to transfer for a bachelor's degree, only $15 \%$ eventually do so (Kahlenberg, 2018). Given these limitations, this chapter focuses on research regarding entrance directly to bachelor's degree-granting colleges and universities.
} 
education. Second, higher education is too complex for central planning; therefore, institutions need to be able to charge differential tuition reflecting their different costs and objectives. Third, in order to maximize the social benefits of universal access, Barr recommends tuition and student living costs initially be paid by government in the form of a student loan and related support grant, making higher education essentially free at access. Given the substantial private benefits they receive from higher education, these student loans should be repaid by the students after graduation based on their current earnings and collected along with income taxes. These loans should also be progressive, charging an appropriate interest rate and providing forgiveness after 25 years to those with lowlifetime earnings. Finally, while Barr assumes a competitive market for mass higher education is most beneficial for society, this market needs to be "well-regulated" with regard quality and efficiency. For example, prestigious universities possess a substantial amount of "market power" because of their ability to attract students regardless of cost; therefore, Barr argues that some form of regulation is needed on institutional tuition.

Consistent with Barr's framework, all bachelor's degree-granting institutions in the US participate in a competitive market and therefore almost all such colleges and universities charge student tuition as well as housing and meal fees for those living on campus. Federal, state, as well as institutional funds provide financial assistance to students in the form of scholarships and grants, loans, and student "work-study" funds. Total US undergraduate student aid in 2018-2019 represented \$186.9 Billion from the following sources: 29\% Federal Loans; 28\% Institutional Grants; 15\% Federal Pell Grants; 8\% Federal Education Tax Benefits; 7\% State Grants; 7\% Private and Employer Grants; 6\% Federal Veterans Benefits (College Board, 2019). The vast majority of US financial aid for higher education applicants is given on the basis of defined economic need, thereby reflecting the previously noted concept of vertical equity. However, "non-needbased aid" (i.e., student scholarships based solely upon academic merit and, as will be discussed below, scholarships based also on athletic talent) are awarded by higher education institutions throughout the 50 US states. Between 1999 and 2011 the percentage of students in the top income quartile receiving non-need aid rose from 13 to $19 \%$ of US undergraduates, while the percentage of students from the bottom income quartile receiving such aid barely changed from 9 to $10 \%$ (Giancola \& Kahlenberg, 2016). 
Applying Barr's framework helps clarify some obvious inequities in the US financial aid system for higher education. First, in the US there is no national regulation of tuition and fees in private higher education. While state governments have often attempted to limit tuition fee increases in public colleges and universities, over the last 25 years' state appropriations per full-time-equivalent (fte) student in the US have declined 8\%, while net tuition per fte student has increased 96\% (SHEEOA, 2019). Public college and university fees now represent almost $50 \%$ of total US public higher education revenue. Second, most US higher education loans, similar to mortgages, have fixed monthly repayments that begin immediately upon graduation, and they must be made over the short period of ten years. Consequently, the US college loan system is regressive. Primarily because of the very large repayment burdens for low-earning bachelor's graduates early in their career, US student default rates have now risen to an all-time high. In contrast, under Barr's guidelines, the regular amount to be paid by a student borrower should depend on his or her income. This both protects low-earning graduates from experiencing financial difficulties or defaulting as well as ensures that taxpayer subsidies are kept low.

Because of the rapidly rising costs of higher education in the US, a number of states have adopted merit-based aid programmes for their residents (Page \& Scott-Clayton, 2016). These state programmes represent the largest increase in US financial aid spending over the last 20 years. Many of these programmes fully cover tuition at in-state public institutions regardless of financial need for applicants who meet a minimum secondary school grade point average (GPA) or SAT/ACT test standard. These policies have been effective in increasing overall college enrolment, student academic performance, and degree attainment. However, these merit-based state aid policies are also inequitable, because a highproportion of the in-state students receiving this tax-based financial assistance would otherwise attend college and come from middle-or upper-class families who could readily afford higher education. In the state of Georgia (Dynarski, 2000) the benefits of a merit-based aid programme based upon student secondary school GPA were concentrated among white students, who experienced a 12.3 percentage point rise in their attendance rate relative to whites in comparison states. Following the adoption of this programme in Georgia the racial gap in public college attendance increased relative to its level in the rest of the Southeast, as did the gap in college attendance between those from low-income and high-income families. 
In addition to caps on tuition, Barr recommended that market regulation include effective quality assurance policies. The amount of US college loans and percentage of student default rates have rapidly risen since the last recession, but an important contributor to this financial burden is the debt of students enrolled in bachelor's or equivalent degrees offered by for-profit higher education (Scott-Clayton, 2018). From 2002 to 2010 these institutions quadrupled their enrolment mainly by targeting relatively vulnerable and poorly informed populations such as African Americans, low-income applicants, and first-generation students. In comparison to non-profit public and private institutions, for-profit bachelor's programmes have had very low student completion rates, poor graduate payment in relevant employment, and four times higher default rates on student federal loans.

To address this problem, the Obama administration Education Department in 2015 adopted a "gainful employment regulation" requiring vocational programmes at for-profit higher education institutions to meet minimum thresholds for the debt-to-income rates of their graduates (Simon, 2018). For-profit vocational programmes that failed to meet these minimum requirements could lose access to all federal financial aid, putting them at a higher risk of closing. In 2016, the Education Department also shut down the Accrediting Council for Independent Colleges and Schools, the nation's largest accreditor of for-profit colleges, arguing it had approved too many dishonest schools. Under the subsequent Trump administration these and related academic quality assurance policies effecting for-profit higher education were reversed. A not surprising policy turn given the widely publicized case involving the closing of Trump University in 2010, a fraudulent for-profit institution set up by the former president.

The US higher education system is already characterized by colleges and universities with variable tuition and fees, market competition for student enrolment, and institutions with substantial autonomy on admissions policy. But the existing government financial aid system often contributes to income inequality. Suggested reforms would include adopting a government-supported loan system covering tuition fees, as well as a grant for living expenses, for all admitted bachelor's degree students. Loan payments following student graduation would be based upon graduates' income and payable for an extended number of years through the national tax system. To be effective such a government financial aid system would also require a more extensive regulation of public and private bachelor's 
degree colleges and universities to ensure acceptable academic quality, student progression, and graduation rates, as well as gainful graduate employment. ${ }^{2}$

\section{INFORMATIONAL AND BEHAVIOURAL CONSTRAINTS FOR LOWER INCOME APPLICANTS}

As an economist Barr (2009) also argues higher education applicants are generally well-informed, or potentially well-informed, consumers and therefore better able than national planners to make choices which conform with their interests and those of the larger economy. This economic assumption has helped spawn the worldwide adoption of college and university "league tables," rankings modelled initially after those developed in America by the magazine US News and World Report. Barr's assumption regarding well-informed student applicants may be more valid in the EU where most students apply to pursue specific subject fields at the bachelor's degree level. But in the US, where the vast majority of students identify and select their subject specialty during their bachelor's degree education, the impacts of these rankings have not always contributed to the efficiency and equity of higher education (Dill \& Soo, 2005).

Information provision is likely to positively influence equitable access to higher education only if quality rankings utilize measures linked with societally valued educational outcomes, students use this information in their choice of subjects, and institutions respond to student choices by improving relevant academic programmes (Gormley \& Weimer, 1999). But many of the commercial rankings in the US (as well as internationally) are not based on any testable theory or model of university educational performance. Instead, US commercial rankings base their assessments primarily on indicators of "academic prestige" such as the quality of enrolled students and of faculty research (Dill \& Soo, 2005). Consequently, in the US many colleges and universities have responded to these rankings, not by efforts to improve the quality of student learning in academic programmes, but by expending greater amounts of time and financial resources on marketing student admissions, as well as investments in athletics, residential facilities, and other amenities attractive to student applicants. These

\footnotetext{
${ }^{2} \mathrm{~A}$ detailed international critique of the US college and university loan system applies a similar economic perspective (see Barr et al., 2017).
} 
over-investments in amenities contribute to the rapidly rising costs of US higher education (Ehrenberg, 2012).

As these investments suggest, the belief institutional "transparency" is an effective means of promoting access to higher education overlooks the evidence of the naïve student consumer, that is, 'young adults [who are] particularly present focused, impulsive, and inexperienced in handling complex tasks' (Page \& Scott-Clayton, 2016, p. 10). A respected study of academic standards in the market-oriented US higher education system concluded, 'there is no reason to expect that students and parents as consumers will prioritize undergraduate learning as an outcome' (Arum \& Roksa, 2011, p. 137).

Furthermore, with regard to fairness of access, some US institutions are seeking to improve their quality rankings by "cream skimming" student applicants, selecting the best-achieving applicants as well as wealthy students most able to pay higher levels of tuition (Dill, 2018). In addition, the increasing focus of rankings on academic research as an indicator of institutional prestige has encouraged US universities to increase the proportion of institutional funds expended on research as a means of improving their rankings. At the same time, the proportion of institutional funds expended on instruction is declining (Ehrenberg, 2012).

One recent approach to college rankings in the US offers a possible model for promoting fair access. A College Access Index developed by the New York Times (NYT) (2017) ranks selective US colleges-those with a five-year graduation rate of at least $75 \%$ - on their commitment to economic diversity. This index is based primarily upon the proportion of each institution's students who receive a Pell Grant, the largest federal scholarship, which is awarded to applicants coming from roughly the bottom 50 or bottom $40 \%$ of the income distribution. All US colleges and universities are required to report how many of their students receive these grants. The ranking indicates how many US low- and middle-income students a college admits and graduates, as well as how much those students must pay for their education. The index therefore provides an indicator of which selective institutions are doing the most to promote social mobility.

The publication of this index has had some influence on college behaviour (Leonhardt, 2017). For example, until recently Princeton was among the least economically diverse US universities. Only $6.5 \%$ of the graduating class of 2007 was in the lower half of the national income distribution. Following the publication of the initial NYT Access Rankings, the Princeton administration actively addressed this issue and the percentage 
of such students has steadily risen to a reported $21 \%$ of the entering class of 2017. The graduation rates of these lower-income students are comparable to the rate of other Princeton students. Princeton is now also increasing its enrolment of middle-class US students as well as low-income foreign applicants.

Barr (2009) does argue while many higher education applicants are fully informed, this knowledge is much less likely for students from poorer backgrounds. These behavioural constraints are evident in the US where low-income students and parents possess less knowledge about higher education and receive poorer information than advantaged students (Dougherty, 2018). These constraints include student and parent understanding of: the net price of selective colleges, after considering financial aid; the academic preparation and test scores sought by selective colleges; the importance of applying for Federal financial aid; the characteristics of different colleges and majors as well as graduation and job placements; and the mechanics of college acceptance including the benefit of applying to multiple colleges.

Taking the SAT/ACT college entrance exams is a key step in the US college application process, but an estimated $30 \%$ of students in the bottom income quartile do so, compared with $70 \%$ of students in the top income quartile (Page \& Scott-Clayton, 2016). Students from many lower income families are much less likely to have college-educated parents, and possessing parents with this knowledge and experience is highly correlated with college application in the US. Lower income parents are also more likely to be engaged in small family-run businesses or farms, which often involve family members as workers. Therefore, these parents may be more debt-averse, less accepting of both the potential financial loss to their business as well as the costs of higher education associated with their children attending college.

In addition, lower income US students and their less-educated parents often find the process of applying for college financial aid complex and intimidating (Page \& Scott-Clayton, 2016). All US college student applicants seeking financial aid must submit a Free Application for Federal Student Aid (FAFSA), a complicated 12-page form. While FAFSA application rates have risen over time, substantial numbers of students eligible for the mentioned Federal Pell Grants programme fail to apply. Many FAFSA applicants also file after required deadlines, decreasing the likelihood of receiving state and institutional aid for which they likely would be eligible. 
Another important consideration for effective college access is "undermatch," in which students enrol in an institution not well aligned to their academic skills and credentials (Deutschlander, 2017; Hoxby \& Avery, 2013). In the US low-income students attending more selective colleges and universities experience much richer instructional as well as extracurricular resources and are also more likely to persist to graduation (Giancola \& Kahlenberg, 2016). But high achieving, low-income US students are often geographically isolated from other high achieving peers and unlikely to encounter either a schoolmate from an older cohort or a teacher who attended a selective college. Consequently, these students tend to make application choices mirroring their socioeconomic rather than academic peers and therefore fail to apply to selective institutions. Because of the strong tradition of local school financing, this geographical isolation is a significant problem in rural areas of the US. As a consequence, it is likely the vast majority of very high achieving students from low-income families in the US do not apply to a college or university which would best serve their needs as well as those of society (Hoxby \& Avery, 2013).

Recognizing the previously noted limitations of information-based guides and college rankings for student choice as well as the behavioural characteristics of low-income families, there have been a number of more active efforts to increase the equity of college access in the US. These have included school-based programmes providing greater access to national college exam testing for lower class students and targeted outreach financial aid counselling and support for low-income families. One carefully designed such outreach effort deserves special mention.

The selective University of Michigan implemented and evaluated an outreach programme designed to address the barriers to fair access experienced by high achieving, low-income US students (Dynarski et al., 2018). Students potentially eligible for the programme were identified using information contained in state administrative databases on student secondary school GPAs, SAT test scores, and eligibility for free or reducedcost school meals. These data were available for Michigan residents for two reasons. First, Michigan had recently required all public high school students to take the SAT college entrance test, and second, a student's participation in the Federally-subsidized school lunch programme indicates they are from families with incomes below the Federal poverty line. Based upon this available information, the university selected a sample of low-income rising senior students in the state who would qualify for both admissions and full financial aid. 
These students were randomly assigned to a pilot programme group and a matched control group. The programme group received personallyaddressed packets at their homes in early September of their senior year of high school. Students in the control group received only postcards listing the University of Michigan application deadlines. The materials sent the programme group were large, glossy, and brightly coloured in the university's signature "maize and blue." The mailing included a letter from the University president encouraging the student to apply and promised a four-year, full-tuition and living expenses scholarship if the student was accepted. The packet also contained brochures explaining the application and admissions process as well as describing the University of Michigan experience. Materials stated prominently that applicants did not have to complete the traditional complex FAFSA form. Information about this offer from Michigan was also later mailed to the students' parents and to High School principals of eligible students asking them to encourage application for the scholarship.

An analysis over time of the matched samples revealed the impact of the Michigan programme intervention. Two-thirds of the high school students involved in the pilot programme applied to the university, compared with only a quarter of similar students in the control group. The share of those in the programme who ultimately enrolled at the University of Michigan was $27 \%$, compared with $12 \%$ from the control group. Without the programme initiative, the increased share of low-income students who chose this selective institution would have predictably made different choices: $4 \%$ of this cohort would not have gone to college, $4 \%$ would have gone to a community college, and $7 \%$ would have gone to a less selective 4 -year college. The effects of the programme also persisted once students entered the University of Michigan, with those participating in the Scholarship programme being $\mathbf{1 3 . 5 \%}$ more likely than those who are in the control group to continue their college enrolment for a second year. The researchers concluded an inexpensive, targeted, personalized outreach campaign can alter the college choices of high achieving low-income students by lessening uncertainty about their suitability for an elite school, correcting their over-estimates of the (net) cost of college, and lowering procedural barriers such as the complexity of financial aid forms.

In sum, research on informational and behavioural constraints for lowincome college applicants in the US raises serious questions about the assumption institutional transparency will effectively assure fair access in mass higher education. Unless rankings of colleges and universities are 
carefully designed to ensure they utilize valid measures linked with societally valued educational outcomes, there is a danger they will instead promote institutional inefficiency and contribute to access inequality. Furthermore, policies to increase access for students of lower income need to involve more active, focused efforts directly related to their financial concerns. The recent effective outreach programme at the University of Michigan further emphasizes the importance to fair access of simplicity and clarity in the design of financial aid policies. This successful US intervention positively influenced parent and student behaviour on college access by making publicly obvious that a family bore no formal responsibility for college financial support and all accepted college applicants would receive the funds necessary to attend higher education.

\section{Affirmative Action Policies}

A third relevant policy consideration for fair access is discrimination. From the perspective of horizontal equity, do valid applicants to US colleges and universities receive equal consideration in the admissions process, or is there discrimination, for example, by student gender, ethnicity, religion, or class.

Historically, colleges and universities in the US excluded racial minorities and women from access to higher education and also limited admission of religious groups such as Catholics and Jews. Because of this discrimination, separate colleges and universities were initially established to serve these excluded populations. ${ }^{3}$ In 1964 the US Civil Rights Act outlawed discrimination in public and private firms based on race, colour, religion, sex, or national origin. Following this Act many colleges and universities voluntarily adopted policies seeking to increase recruitment of racial minorities under the banner of Affirmative Action. Initially some of these admissions procedures included the use of racial quotas until the US Supreme Court questioned their constitutionality. The Court subsequently clarified race could be used as one of several factors in individual admissions decisions without necessarily violating the equal protection clause of the 14th Amendment. The Court's original decision supported

\footnotetext{
${ }^{3}$ US colleges and universities currently include 35 women's colleges, 101 historically Black institutions, and over 7000 colleges and universities reporting a religious affiliation. The latter institutions include Catholic, Jewish, and Islamic institutions as well as the many different protestant denominations (NCES, 2019).
} 
diversity in higher education as a "compelling interest," but as Justice O'Connor noted in a later 2003 decision: 'We expect that 25 years from now the use of racial preferences will no longer be necessary to further the interest approved today' (Thomas, 2019).

As access to higher education has become increasingly influential on a person's life chances, public opposition to Affirmative Action in US college admissions has grown. A recent national survey (Pew Research Center, 2019) reports 73\% of Americans now say colleges and universities should not consider race or ethnicity when making decisions about student admissions. Reflecting this attitude seven additional states have followed California's 1996 decision to prohibit preferential treatment for applicants to state supported universities on the basis of race, sex, ethnicity, or national origin (Baker, 2019). In the wake of these bans, the enrolment of underrepresented racial and ethnic minority students has decreased at selective public US colleges and universities in the relevant states.

The decline of minority enrolment in selective colleges may be particularly damaging to society. As previously noted selective US colleges and universities are a better fit or match for high achieving low-income students, who are more likely to progress and graduate from these institutions. Furthermore, an influential economic study (Dale \& Krueger, 2014) uncovered an additional critical factor. The researchers discovered the higher average salaries over time predicted for graduates of highly selective US universities were more a product of the talents of their admitted students than of their educational programmes. That is, individuals accepted at highly selective colleges who instead enrolled in less selective institutions had similar incomes, as did the graduates of the elite schools. But Latino, black, and low-income students proved an exception. These students who were accepted at highly selective schools and who instead attended less selective institutions had lower average salaries over time. The researchers believed networking opportunities available from attending a selective college may be particularly valuable for the life chances of black and Hispanic students and for students who come from families with a lower level of parental education. This positive influence of elite institutions may be especially important in the US. Since the first Supreme Court decision on Affirmative Action, there has been continuing job discrimination, particularly against African Americans, as recent research on pay and job placement of minorities indicates (Quillian et al., 2017).

Similarly, a recent comprehensive economic study (Bleemer, 2020) finds that by nearly every measure, the ban on race-based Affirmative 
Action in California's selective public universities has harmed underrepresented minority (URM) students, decreasing their number in the University of California system while reducing their odds of finishing college, going to graduate school and earning a high salary. At the same time, the policy did not appear to greatly benefit the white and Asian-American students who took their place.

In California, the effect of the ban on the state's elite universities was immediate. URM enrolment at the flagship Berkeley and Los Angeles campuses fell steeply. The ban also depressed the number of highly qualified URM high school students who applied to the overall University of California system, perhaps because they mistakenly believed they would not be accepted. The study assembled a database of every student who applied to the eight undergraduate campuses of the University of California from 1994 to 2002, including their high school grades, demographics, income, and SAT scores. The study tracked where they went to college, their academic majors and degrees, and how much they earned in the job market for years after graduation. After the ban fully took effect in 1998, URM students who would have enrolled at the flagship campuses before the ruling attended less selective universities in the system. This in turn pushed out other URM students, who moved down the ladder of selectivity. Those at the bottom lost their grip entirely, exiting the system altogether. It is noteworthy that if URM students had benefited from enrolling in less selective universities, they would have been more successful in rigorous math and science courses there. Instead, they were less likely to earn bachelor's degrees in a science or engineering field and less likely to graduate over all, compared with URM students before the ban. They were also less likely to earn graduate degrees.

The study discovered differences in the URM students' college classroom success, compared with white and Asian-American students, appeared to be largely explained by lower-quality preparation in K-12 schools, not admissions preferences. Because of the ban, students of colour in the study earned 5\% less on average every year, an effect that persisted into their mid-30s, when the study period ended. For every Black and Hispanic student who was excluded by the ban, another student, probably white or Asian-American, took their place. But the study discovered, similar to Dale and Krueger's (2014) research on selective US public and private universities, that the replacement white and Asian-American students received little concrete benefit from the Affirmative Action ban. The study suggests these replacement students would have otherwise enrolled in an 
equally selective college elsewhere, and had the same chances to graduate and begin successful careers. In sum, the Affirmative Action ban on the most selective public universities in California lowered the social and economic benefits of public higher education to the state. It set back a generation of Black and Hispanic students, pushing them down and out of the University of California system and helped to widen the existing racial wealth gap, with seemingly little offsetting benefits for other students.

The public reaction to possible bias for minorities in college admissions is also largely uninformed by the existing admissions preferences at selective US colleges and universities. As recent court cases on US college admissions have suggested and as substantive research has confirmed (Arcidiacono et al., 2019; Bowen \& Levin, 2003; Shulman \& Bowen, 2000 ), there are as strong or stronger admissions preferences in favour of recruited athletes, legacies, and the children of institutional faculty and staff as there are for underrepresented minorities. A court case involving Harvard University, one of the highest ranked and most selective universities in the US, for the first time provided publicly available institutional data on domestic undergraduate applications and admissions (Arcidiacono et al., 2019). Table 3.1 is based on applications for the entering classes of 2010-2015. It provides admit rates for applicants by race as well as by preference groups, such as recruited athletes, legacies, children of Harvard faculty and staff, as well as the Dean's/Director's Interest List, which rates

Table 3.1 Harvard domestic applicants/ admits by race and ALDC status, 2010-2015

\begin{tabular}{llc}
\hline & \# of applications & $\begin{array}{l}\text { Admit } \\
\text { rate }\end{array}$ \\
\hline White & 57,582 & 4.89 \\
Black & 15,664 & 7.58 \\
Hispanic & 17,970 & 6.16 \\
Asian & 40,415 & 5.13 \\
(A) Recruited athlete & 1374 & 86.0 \\
(L) Legacy & 4644 & 33.6 \\
(D) Dean/director rating & 2501 & 42.2 \\
(C) Faculty/staff children & 321 & 46.7 \\
Not ALDC & 142,728 & 5.45 \\
TOTAL & 166,727 & 6.67 \\
\hline
\end{tabular}

Note: ALDC refers to recruited athletes, legacies, those on the dean's interest list, and children of faculty and staff

Source: Arcidiacono et al. (2019) 
applicants whose family has donated financially to Harvard and who are likely future donors. As the Table indicates there is some preference in admissions given to minority applicants, but these preferences are modest compared to the weight of other listed preference categories which, with the exception of Harvard children, tend to favour white applicants from higher income families.

The Harvard preferences for athletes and legacies are common to admissions decisions studied in other selective US public and private colleges and universities (Bowen \& Levin, 2003; Shulman \& Bowen, 2000). In the US public mind, preferences for recruited athletes may be associated with minority enrolment, because of the visibly high proportion of black students engaged in college and university football, basketball, and track teams. But other than these sports at NCAA Division I universities, ${ }^{4}$ the vast majority of athletes recruited to selective and non-selective US colleges and universities including Harvard are white. Furthermore, Division I recruited athletes in many university sports are provided full tuition and living expenses scholarships and these scholarships are awarded based on athletic ability not financial need. ${ }^{5}$

Legacy admission preferences were initiated among elite US universities following World War I in order to limit the admission of able immigrants, particularly Jews (Schmidt, 2010). As Jewish applicants often surpassed traditional constituencies on standard meritocratic criteria, universities adopted Jewish quotas. When specific quotas became difficult to defend, the universities employed more indirect means to limit Jewish enrolment, including considerations of "character," geographic diversity, and legacy status. Over time, legacy preferences became exceedingly popular among US college alumni and were widely adopted. Among the US top 100 national universities ranked in U.S. News \& World Report, roughly three quarters employed legacy preferences in admissions and among the top 100 liberal arts colleges, virtually all do (Coffman et al., 2010).

\footnotetext{
${ }^{4}$ Division I is the highest level of intercollegiate athletics overseen by the US National Collegiate Athletic Association. These 350 bachelor-degree granting colleges and universities comprise the major athletic powers in the US collegiate ranks and have larger budgets, more advanced facilities, and offer more athletic scholarships than smaller schools.

${ }^{5}$ Harvard and other universities in the "Ivy League" are not part of the NCAA Division I and do not formally offer "athletic scholarships." But as noted, most selective US colleges and universities, including Harvard and other Ivy League universities, provide intercollegiate sports programmes and give athletes preference in admissions (Bowen \& Levin, 2003; Shulman \& Bowen, 2000).
} 
The publicly stated rationale for this policy by Harvard (Arcidiacono et al., 2019) is to provide a means of sustaining alumni engagement as reflected in their financial donations to the university as well as in their active volunteer efforts to recruit and interview student applicants. But while Harvard's Dean's/Director's Interest List gives special admissions preference to applicants whose family donated financially to the university, most institutions give admissions preference to all alumni children applicants. Consequently, economic research on the top 100 US universities (Coffman et al., 2010), which controlled for the wealth of alumni, provided no evidence legacy-preference policies themselves exert an influence on alumni giving behaviour. The researchers also examined giving at seven institutions that dropped legacy preferences during the period of the study and found no short-term measurable reduction in alumni giving as a result of the abolition of legacy preferences. For example, after Texas A\&M University eliminated the use of legacy preferences in 2004, donations slightly declined, but then increased substantially from 2005 to 2007.

From the perspective of fair access to higher education, the evidence of the admission preferences employed by US college and universities is difficult to defend. While the biases favouring athletes and legacies may be unique to the US, the global development of mass higher education with competitive markets and academic rankings may induce other institutions to emulate the US preferences awarded to wealthy donors and alumni. It is worth noting alumni financial donations is one of the quality measures used in the US News and World Report rankings of American colleges and universities.

With regard affirmative action, the US Supreme Court in their last college admissions ruling challenged the US states and universities to find workable race-neutral strategies to achieve educationally-beneficial diversity (Baker et al., 2018). Because members of US minority groups are often of low income, some scholars (Kahlenberg, 2018) have advocated affirmative action admissions policies with preferences for socioeconomic class (SEC) rather than race. A recent rigorous simulation study of SECbased admissions policies (Baker et al., 2018) indicates they would benefit US low-income applicants, but would not be as effective in aiding diversity as current race-sensitive university admissions policies. The researchers noted race-sensitive affirmative action leads to racial diversity because it can select directly the students who will contribute most to racial variety on a campus. SEC-based affirmative action would require a strong relationship between SEC and race in order to achieve racial diversity. Their 
simulation study made clear even unusually strong SEC-based policies would only produce about half the diversity achieved under race-sensitive policies. However, the researchers argued the combination of an SECbased admissions policy with a programme of targeted race-based recruiting and outreach offers the potential to yield racial diversity levels comparable to race-sensitive admissions policies. This type of targeted recruitment and outreach appears similar to the previously described scholarship intervention effort of the University of Michigan.

This brief review of possible discrimination in US college and university admissions decisions reveals a number of policy issues of possible relevance to other nations. First, as other countries "massify" their higher education systems many are also introducing tuition fees, promoting market competition for students among universities, and awarding greater administrative autonomy to academic institutions. The existing preferences in US admissions for students from wealthy alumni and families emerged in a system characterized by institutional autonomy, tuition-charging universities, as well as market competition for students and financial resources. The US example therefore suggests some possible issues for sustaining fair access in evolving admissions policies for higher education. Second, the US preferences embodied in affirmative action admissions policies raise challenging questions regarding horizontal equity. Within the US legal system, admissions preferences based on race and ethnicity have been strongly defended as compensatory policies necessitated by historical discrimination. But many of the minority students currently admitted to US selective institutions are from middle- and upper-class families (Giancola \& Kahlenberg, 2016). The US experience therefore raises the critical issue of how best to determine who is most deserving of compensatory consideration for past discriminatory action.

\section{Conclusion}

The US experience on access and inequality in higher education admissions suggests a number of policy design issues for mass systems of higher education in developed nations.

First, US policy for higher education confirms many of Barr's (2009) points about the design of efficient and equitable student financial aid. The lack of effective US regulation of public and private college and university tuition as well as academic quality has encouraged inefficient market competition. As a result, US college tuition and costs have rapidly 
risen, but student tuition and university fees have been diverted into costly investments for athletics, residential facilities, and other amenities attractive to student applicants. These funds have also subsidized academic research. As a consequence, the proportion of college and university finances expended on instruction is declining. The design of the US student loan programme also does not reflect Barr's recommendations that loan repayments be made via income tax, be income contingent, and include interest based upon government's cost of borrowing. Therefore, the US student loan system has had punishing financial consequences for many young graduates, especially those from low-income families who have incurred large debts and defaulted on their loans. In addition, because of lax accreditation standards, the Federal Loan system has been exploited by profit-making higher education. Finally, the award of competitive, merit-based financial aid by many institutions, as well as by a number of US states, has disproportionally favoured students from wealthy families.

Second, a policy emphasis on institutional transparency as a means of improving access to higher education underestimates the negative effects of consumer naiveté as well as the informational and behavioural constraints experienced by lower income applicants. Because disadvantaged US students and parents possess less knowledge and experience regarding higher education, a large proportion of high achieving, low-income students under match in their choice of college. Consequently, these students thereby fail to achieve the quality of education most beneficial to themselves and to American society. One means of addressing this weakness would be requiring institutions and published quality rankings to include information on how much admissions decisions promote social mobility (e.g., how many low- and middle-income students a college or university admits and graduates). Financial aid systems for bachelor's degree students also need to be easily accessible and universal, clearly communicating student eligibility for aid and the amount of possible financial support, as do the systems in Australia and England. Even with such a financial aid system, the circumstances confronting disadvantaged families warrant adoption of policies to encourage the most selective institutions to engage in targeted, personalized recruitment efforts to encourage and guide bachelor's applications from able, low-income students.

Third, the US experience with admission preferences and affirmative action suggests several issues for admissions policy in other nations. The demonstrated admission preferences in bachelor's degree admissions for athletes, legacies, and faculty children may be distinctive to the US, but 
adoption of market competition in the expansion of other nations' higher education systems has created greater incentives for institutions to seek paying students as well as financial resources to help boost academic prestige. In this environment, there is likely greater need to carefully monitor institutional admission procedures to assure an appropriate focus on true academic potential and merit. There is also evidence in some EU countries of "positive action" policies (O'Cinneide, 2009) designed to assure access of women to higher education, jobs, and professional opportunities. As the migration of ethnic and religious minorities into developed nations continues to increase, it is likely EU nations may also confront issues of discrimination, ${ }^{6}$ policy debate, and public reaction similar to those experienced in the US. For this reason, knowledge about the US experience with affirmative action policy in college and university admissions may also be of value.

As many countries massify their systems of higher education, assuring equity and fairness in college and university admissions will continue to be a significant policy issue.

Acknowledgements I am indebted to Professors Steven Hemelt and Claire Callender for valuable suggestions, but remain solely responsible for the words and arguments presented.

\section{REFERENCES}

Arcidiacono, P., Kinsler, J., \& Ransom, T. (2019). Legacy and Athlete Preferences at Harvard. NBER Working Paper No. 26316. National Bureau of Economic Research. Retrieved from https://www.nber.org/papers/w26316

Arum, R., \& Roksa, J. (2011). Academically Adrift: Limited Learning on College Campuses. University of Chicago Press.

Baker, D. J. (2019). Pathways to Racial Equity in Higher Education: Modelling the Antecedents of State Affirmative Action Bans. American Educational Research Journal, 56(5), 1861-1895.

Baker, R., Kasman, M., Klasik, D., \& Townsend, J. B. (2018). What Levels of Racial Diversity Can Be Achieved with Socioeconomic-Based Affirmative Action? Evidence from a Simulation Model. Journal of Policy Analysis and Management, 37(3), 630-657.

\footnotetext{
${ }^{6}$ Quillian et al. (2019) report evidence of significant job discrimination against non-white natives in many EU countries.
} 
Barr, N. (2009). Financing Higher Education: Lessons from Economic Theory and Reform in England. Higher Education in Europe, 34(2), 201-209.

Barr, N., Chapman, B., Dearden, L., \& Dynarski, S. (2017). Getting Student Financing Right in the US: Lessons from Australia and England. Centre for Global Higher Education Working Paper 16. UCL Institute of Education. Retrieved from https://www.researchcghe.org/perch/resources/publications/wpl6.pdf

Bleemer, Z. (2020). Affirmative Action, Mismatch, and Economic Mobility after California's Proposition 209. Centre for Studies of Higher Education Occasional Paper: CSHE.10.2020. Retrieved from https://cshe.berkeley.edu/sites/ default/files/publications/rops.cshe.10.2020.bleemer. prop209.8.20.2020_2.pdf

Bowen, W. G., \& Levin, S. A. (2003). Reclaiming the Game: College Sports and Educational Values. Princeton University Press.

Chappell, B., \& Kennedy, M. (2019). U.S. Charges Dozens of Parents, Coaches in Massive College Admissions Scandal. NPR. Retrieved from https://www.npr.

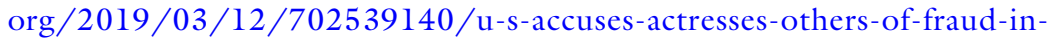
wide-college-admissions-scandal

Coffman, C., O’Neil, T., \& Starr, B. (2010). An Empirical Analysis of the Impact of Legacy Preferences on Alumni Giving at Top Universities. In R. D. Kahlenberg (Ed.), Affirmative Action for the Rich: Legacy Preferences in College Admissions (pp. 101-121). Century Foundation Press.

College Board. (2019). Trends in Student Aid 2019. College Board. Retrieved from https://research.collegeboard.org/pdf/trends-student-aid-2019full-report.pdf

Dale, S. B., \& Krueger, A. B. (2014). Estimating the Effects of College Characteristics Over the Career Using Administrative Earnings Data. Journal Human Resources, 49(2), 323-358.

Deutschlander, D. (2017). Academic Undermatch: How General and Specific Cultural Capital Structure Inequality. Sociological Forum, 32(1), 162-185.

Dill, D. D. (2018). Can Public Policy Promote Academic Quality?: An Assessment of Policy Instruments for Instruction and Research. In E. Hazelkorn, H. Coates, \& A. C. McCormick (Eds.), Research Handbook on Quality, Performance and Accountability in Higher Education (pp. 42-55). Edward Elgar.

Dill, D. D., \& Soo, M. (2005). Academic Quality, League Tables, and Public Policy: A Cross-National Analysis of University Ranking Systems. Higher Education, 49(4), 495-533.

Dougherty, K. J. (2018). Higher Education Choice-Making in the United States: Freedom, Inequality, Legitimation. Centre for Global Higher Education Working Paper 35, UCL Institute of Education. Retrieved from https://www. researchcghe.org/publications/working-paper/higher-education-choicemaking-in-the-united-states-freedom-inequality-legitimation/ 
Dynarski, S. (2000). Hope for Whom? Financial Aid for the Middle Class and Its Impact on College Attendance. National Tax Journal, 53(3), 629-661.

Dynarski, S., Libassi, C. J., Michelmore, K., \& Owen, S. (2018). Closing the Gap: The Effect of a Targeted, Tuition-Free Promise on College Choices of HighAchieving, Low-Income Students. NBER Working Papers 25349, National Bureau of Economic Research. Retrieved from https://www.nber.org/ papers/w25349

Ehrenberg, R. G. (2012). American Higher Education in Transition. Journal of Economic Perspectives, 26(1), 193-216.

Giancola, J., \& Kahlenberg, R. D. (2016). True Merit: Ensuring Our Brightest Students Have Access to Our Best Colleges and Universities. Jack Kent Cooke Foundation. Retrieved from https://www.jkcf.org/research/ true-merit-ensuring-our-brightest-students-have-access-to-our-best-collegesand-universities/

Gormley, W. T., \& Weimer, D. L. (1999). Organizational Report Cards. Harvard University Press.

Heckman, J. (2019). The Heckman Curve. Retrieved from https://heckmanequation.org/resource/the-heckman-curve/

Hoxby, C. M., \& Avery, C. (2013). Missing 'One-Offs': The Hidden Supply of High-Achieving, Low-Income Students (pp. 1-65). Brookings Papers on Economic Activity, Spring.

Kahlenberg, R. D. (2018, October 12). We Still Need Affirmative Action - Just not by Race. Boston Globe. Retrieved from https://www.bostonglobe.com/ ideas $/ 2018 / 10 / 12 /$ still-need-affirmative-action-just-not-race/dDAPCPn0MHBjrLAh8S5FiN/story.html

Leonhardt, D. (2017). Princeton - Yes, Princeton - Takes on the Class Divide. New York Times. Retrieved from https://www.nytimes.com/2017/05/30/ opinion/princeton-takes-on-class-divide.html

LeTendre, G. K., Hofer, B. K., \& Shimizu, H. (2003). What Is Tracking? Cultural Expectations in the United States, Germany, and Japan. American Educational Research Journal, 40(1), 43-89.

National Center for Education Statistics (NCES). (2018). Digest of Education Statistics: Table 302.10. Retrieved from https://nces.ed.gov/programs/ digest/d18/tables/dt18_302.10.asp

National Center for Education Statistics (NCES). (2019). College Navigator. National Center for Education Statistics. Retrieved from https://nces.ed.gov/ collegenavigator/

New York Times. (2017). Top Colleges Doing the Most for the American Dream. New York Times Magazine. Retrieved from https://www.nytimes.com/interactive $/ 2017 / 05 / 25 /$ sunday-review/opinion-pell-table.html 
O'Cinneide, C. P. (2009). Positive Action. In Y. Lee \& J. Goldschmidt (Eds.), Taking Employment Discrimination Seriously: Chinese and European Perspectives (pp. 279-306). Brill.

OECD. (2015). In It Together - Why Less Inequality Benefits All. OECD Publishing. Figure 1.3. Retrieved from https://read.oecd-ilibrary.org/employment/in-ittogether-why-less-inequality-benefits-all_9789264235120-en\#page l

OECD. (2018). A Broken Social Elevator? How to Promote Social Mobility. OECD Publishing. Retrieved from https://read.oecd-ilibrary.org/social-issuesmigration-health/broken-elevator-how-to-promote-social-mobility_9789264 301085-en\#pagel

OECD. (2019). Population with Tertiary Education. Retrieved from https:// data.oecd.org/eduatt/population-with-tertiary-education.htm

Page, L. C., \& Scott-Clayton, J. (2016). Improving College Access in the United States: Barriers and Policy Responses. Economics of Education Review, 51, 4-22.

Pew Research Center. (2019). Race in America 2019. Retrieved from https:// www.pewresearch.org/social-trends/2019/04/09/race-in-america-2019/

Quillian, L., Heath, A., Pager, D., Midtbøen, A. H., Fleischmann, F., \& Hexel, O. (2019). Do Some Countries Discriminate More Than Others? Evidence from 97 Field Experiments of Racial Discrimination in Hiring. Sociological Science, 6, 467-496.

Quillian, L., Pager, D., Hexel, O., \& Midtbøen, A. (2017). Meta-analysis of Field Experiments Shows no Change in Racial Discrimination in Hiring Over Time. Proceedings of the National Academy of Sciences, 114(41), 10870-10875.

Schmidt, P. (2010). A History of Legacy Preferences and Privilege. In R. D. Kahlenberg (Ed.), Affirmative Action for the Rich: Legacy Preferences in College Admissions (pp. 50-70). Century Foundation Press.

Scott-Clayton, J. (2018). The Looming Student Loan Default Crisis Is Worse Than We Thought. Brookings Institution. Retrieved from https://www.brookings. edu/wp-content/uploads/2018/01/scott-clayton-report.pdf

Shulman, J. S., \& Bowen, W. G. (2000). The Game of Life: College Sports and Educational Values. Princeton University Press.

Simon, C. (2018). For-Profit Colleges' Teachable Moment: Terrible Outcomes Are Very Profitable. Forbes. Retrieved from https://www.forbes.com/sites/ schoolboard/2018/03/19/for-profit-colleges-teachable-moment-terribleoutcomes-are-very-profitable/\#76bdedc740f5

State Higher Education Executive Officers Association (SHEEOA). (2019). State Higher Education Finance: FY 2018. State Higher Education Executive Officers Association. 
Thomas, E. (2019, March 19). Why Sandra Day O'Connor Saved Affirmative Action. The Atlantic. Retrieved from https://www.theatlantic.com/ideas/archive/2019/03/how-sandra-day-oconnor-savedaffirmative-action/584215/

Weimer, D., \& Vining, A. R. (2017). Policy Analysis: Concepts and Practice. Routledge.

Open Access This chapter is licensed under the terms of the Creative Commons Attribution 4.0 International License (http://creativecommons.org/licenses/ by $/ 4.0 /$ ), which permits use, sharing, adaptation, distribution and reproduction in any medium or format, as long as you give appropriate credit to the original author(s) and the source, provide a link to the Creative Commons licence and indicate if changes were made.

The images or other third party material in this chapter are included in the chapter's Creative Commons licence, unless indicated otherwise in a credit line to the material. If material is not included in the chapter's Creative Commons licence and your intended use is not permitted by statutory regulation or exceeds the permitted use, you will need to obtain permission directly from the copyright holder.

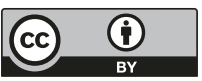

